\title{
FORMULASI SEDIAAN LULUR PENCERAH DAN PENGHALUS KULIT DARI KUNYIT (CURCUMA LONGA LINN) Rani Prabandani ${ }^{1)}$ Hilda Suherman ${ }^{2)}$ \\ ${ }^{1), 2)}$ Program Studi Farmasi Sekolah Tinggi Ilmu Kesehatan Harapan Bangsa Purwokerto \\ ${ }^{1)}$ Raniprabandari@shb.ac.id, ${ }^{2)}$ hildasuherman@shb.ac.id
}

\begin{abstract}
ABSTRAK
Lulur adalah jenis kosmetik yang dibuat dari bunga-bunga dan bahan-bahan tanaman lainya yang sangat bermanfaat untuk menjaga kecantikan, kesehatan, kehalusan dan kecerahan kulit tubuh. Lulur dapat membantu membersihkan kotoran yang menempel dikulit akibat pengaruh faktor cuaca dan polusi sehingga kulit menjadi sehat, bersih dan cantik. Jenis kulit kering sering cendrung lebih bermasalah dibanding jenis kulit lainnya. Kulit kering disebabkan karena tidak cukupnya minyak yang dihasilkan oleh kelenjer minyak, sehingga membuat kulit tidak lembab dan menjadi kering. Hal ini dapat menimbulkan masalah pada kulit seperti: kulit terlihat kasar, berkeriput dan kusam. Kandungan zat senyawakunyit antara lain:kurkuminoid yangterdiri dari kurkumin, desmetoksikumin dan bisdesmetoksikurkumin serta zat-zat manfaat lainnya, seperti minyak asiri volatil oil, lemak, karbohidrat, protein, pati, vitamin $\mathrm{C}$, zat besi, fosfor, dan kalsium. Curcumin adalah zat warna kuning yang dikandung oleh kunyit, rata-rata 10,29\%, memiliki aktifitas biologis berspektrum luas antara lain antihepototoksik, antibakteri dan antioksidan sehingga kunyit mampu digunakan untuk obat tradisional baik menjaga esehatan maupun kecantikan kulit tubuh, Metode yang digunakan untuk melaksanakan penelitian ini adalah eksperimen. Objek dalam penelitian ini adalah kulit tubuh yang terdapat pada kulit kering pada bagian tangan. Sampel dalam penelitian ini penulis mengambil mahasiswa Universitas Harapan Bangsa Purwokerto Jurusan Farmasi khususnya wanita usia 19-25 tahun, memiliki karekteristik/kriteria yang sama yang terindikasi kulit kusam, kasar dan tidak cerah.
\end{abstract}

Kata kunci : formulasi, lulur, kunyit, pencerah.

\begin{abstract}
Lulur is a type of cosmetics made from flowers and other plant ingredients that are very useful for maintaining beauty, health, smoothness and brightness of the skin of the body. Scrub can help clean the dirt that sticks to the skin due to the influence of weather factors and pollution so that the skin becomes healthy, clean and beautiful. Dry skin types often tend to be more problematic than other skin types. Dry skin is caused by insufficient oil produced by the kelenjer oil, which makes the skin not moist and dry. This can cause skin problems such as: skin looks rough, wrinkled and dull. The contents of the substance include turmeric: curcuminoid which consists of curcumin, desmetoksikumin and bisdesmetoksikurkumin and other beneficial substances, such as volatile essential oils of oil, fat, carbohydrates, protein, starch, vitamin C, iron, phosphorus, and calcium. Curcumin is a yellow substance contained by turmeric, on average 10.29\%, has broad spectrum biological activity including antihepototoxic, antibacterial and antioxidant so that turmeric is able to be used for traditional medicine both maintaining health and beauty of the body's skin, the method used to carry out this research is an experiment. The object in this study is the skin of the body found on dry skin in the hands. The sample in this study the author took the students of the University of Harapan Bangsa Purwokerto Pharmacy Department especially women aged 19-25 years, have the same characteristics / criteria that indicated dull, rough and not bright skin.
\end{abstract}

Keywords: formulation, scrub, turmeric, lightening. 


\section{PENDAHULUAN}

Kesehatan merupakan salah satu kebutuhan dasar manusia, itulah sebabnya upaya untuk mencapai tingkat kesehatan yang optimal sangat diperlukan. Berbagai upaya dilakukan masyarakat untuk hidup dengan sehat bersama keluarga. Sebelum zaman berkembang pada umumnya masyarakat melakukan pengobatan tradisional yang bahan dasar obatnya berasal dari tumbuhan- tumbuhan yang mereka kenal dan berfungsi sebagai obat (Prakash, 2001).

Dalam perawatan, mengenal jenis kulit merupakan hal utama yang harus dilakukan supaya tidak terjadi kesalahan dalam memilih kosmetika serta menentukan teknik perawatannya. Jenis kulit tersebut dapat dibedakan atas beberapa jenis yakni: (1) jenis kulit kering (2) jenis kulit berminyak (3) jenis kulit kombinasi dan (4) jenis kulit normal, Nur'an (2009:43-45).

Jenis kulit kering sering cendrung lebih bermasalah dibanding jenis kulit lainnya. Kulit kering disebabkan karena tidak cukupnya minyak yang dihasilkan oleh kelenjer minyak, sehingga membuat kulit tidak lembab dan menjadi kering. Hal ini dapat menimbulkan masalah pada kulit seperti: kulit terlihat kasar, berkeriput dan kusam.

Kunyit dengan bahasa saintifiknya bernama Curcuma domestica Val. Depkes RI, (2002) menyatakan selain tanaman kunyit sebagai bumbu dapur, kunyit juga digunakan untuk kecantikan kulit, melindungi kulit tubuh akibat sinar matahari. Kandungan zat senyawakunyit antara lain:kurkuminoid yangterdiri dari kurkumin, desmetoksikumin dan bisdesmetoksikurkumin serta zat-zat manfaat lainnya, seperti minyak asiri volatil oil, lemak, karbohidrat, protein, pati, vitamin C, zat besi, fosfor, dan kalsium. Curcumin adalah zat warna kuning yang dikandung oleh kunyit, rata-rata 10,29\%, memiliki aktifitas biologis berspektrum luas antara lain antihepototoksik, antibakteri dan antioksidan sehingga kunyit mampu digunakan untuk obat tradisional baik menjaga esehatan maupun kecantikan kulit tubuh, (DokterGaul.com-27/08/2012/net).

Dalam hal ini, dikarenakan seringnya mengabaikan kesehatan dan kurangnya melakukan perawatan kulit tubuh. Misalnya, pada saat mereka keluar rumah/berpergian, mereka tidak menggunakan payung, tidak menggunakan pelindung (sunblock), juga faktor cuaca, 
polusi, debu dan paparan sinar matahari yang terus membakar kulit, sehingga terdapatnya sel-sel kulit mati, sel-sel kulit mati inilah yang dapat menyebabkan pigmentasi kusam pada kulit tubuh. Kulit kusam jelas akan mengurangi keindahan kulit, kulit terlihat kasar dan kusam,hal ini mengurangi daya tarik penampilan seseorang dalam bergaul.

Terkait dengan hal di atas jelaslah bahwa upaya yang aman dilakukan dalam perawatan kulit tubuh adalah dengan menggunakan lulur. Lulur adalah jenis kosmetik yang dibuat dari bunga-bunga dan bahan-bahan tanaman lainya yang sangat bermanfaat untuk menjaga kecantikan, kesehatan, kehalusan dan kecerahan kulit tubuh. Lulur dapat membantu membersihkan kotoran yang menempel dikulit akibat pengaruh faktor cuaca dan polusi sehingga kulit menjadi sehat, bersih dan cantik.

\section{METODE PENELITIAN}

Metode yang digunakan untuk melaksanakan penelitian ini adalah eksperimen. Eksperimen ini termasuk kepada pre-eksperimen yang merupakan eksperimen dilakukan dengan tanpa melakukan pengendalian terhadap variabel-variabel yang berpengaruh dalam penelitian ini yang diutamakan adalah perlakuan saja, tanpa ada kelompok control (Saifuddin Azwar, 2007:10).

Adapun objek dalam penelitian ini adalah kulit tubuh yang terdapat pada kulit kering pada bagian tangan. Sampel dalam penelitian ini penulis mengambil mahasiswa Universitas Harapan Bangsa Purwokerto Jurusan Farmasi khususnya wanita usia 19-25 tahun, memiliki karekteristik/kriteria yang sama yang terindikasi kulit kusam, kasar dan tidak cerah.

Pengambilan sampel dilakukan dengan teknik purposive sampling yaitu teknik penentuan sampel dengan pertimbangan tertentu (Sugiono, 2006:95) dengan kriteria yang disebut di atas yang dilaksanakan dengan cara volunteer sampling, Yusuf (2005:207) mengatakan bahwa orang yang dijadikan sampel atau responden ditetapkan secara volunter yaitu sukarela dan mau memberikan informasi. Jenis data yang digunakan dalam penelitian ini adalah data primer dan penelitin ini diperoleh dengan perlakuan terhadap 5 orang sampel homogen.

Dalam penelitian ini teknik pengumpulan data yang digunakan yaitu teknik observasi, metode dokumentasi dan 
instrumen penilaian. Penilaian perawatan kulit tubuh diamati dari kehalusan dan kecerahan kulit. Data hasil percobaan dinilai dari pengisian kuisioner untuk menjawab semua pertanyaan peneliti. Setelah diperoleh data, indikator kehalusan dan kecerahan dilakukan deskriptif rata-rata masing-masing sampel dan selanjutnya data ditabulasi dalam bentuk tabel. Setelah data dikelompokan dalam tabel-tabel tertentu, dilakukan analisis uji normalitas dan uji homogenitas serta uji hipotesis adalah untuk mengetahui apakah terdapat pengaruh pemanfaatan lulur pencerah kulit dari kunyit terhadap perawatan kulit tubuh dengan menggunakan uji t (one sample $\mathrm{t}$ tes).

\section{HASIL DAN PEMBAHASAN}

1. Uji Normalitas

Uji normalitas yang dilakukan untuk melihat apakah data penelitian ini berdistribusi normal atau tidak, dengan menggunakan uji KolmogorovSmirnov (SPSS 16), data berdistribusi normal (Ha diterima) apabila nilai probalistas atau tingkat signifikan diatas 0,05 . Output uji normalitas dapat dilihat pada tabel kehalusan dan kecerahan sebagai berikut:

Tabel 5. Uji Normalitas

\begin{tabular}{|c|c|c|c|c|}
\hline \multicolumn{5}{|c|}{ Tests of Normality } \\
\hline & \multirow{2}{*}{$\begin{array}{l}\text { sampe } \\
1\end{array}$} & \multicolumn{3}{|c|}{ Kolmogorov-Smirnov ${ }^{\mathrm{a}}$} \\
\hline & & Statistic & $\mathrm{Df}$ & Sig. \\
\hline \multirow[t]{5}{*}{ kehalusan } & 1 & .225 & 8 & .125 \\
\hline & 2 & .205 & 8 & $.200^{\circ}$ \\
\hline & 3 & .220 & 8 & $.200^{\circ}$ \\
\hline & 4 & .220 & 8 & $.200^{*}$ \\
\hline & 5 & .220 & 8 & $.200^{*}$ \\
\hline
\end{tabular}

\begin{tabular}{|c|c|c|c|c|}
\hline \multicolumn{5}{|c|}{ Tests of Normality } \\
\hline & \multirow{2}{*}{$\begin{array}{l}\text { sampe } \\
1\end{array}$} & \multicolumn{3}{|c|}{ Kolmogorov-Smirnov $^{a}$} \\
\hline & & Statistic & Df & Sig. \\
\hline \multirow[t]{5}{*}{ kecerahan } & 1 & .263 & 8 & .109 \\
\hline & 2 & .235 & 8 & $.200^{\circ}$ \\
\hline & 3 & .205 & 8 & $.200^{\circ}$ \\
\hline & 4 & .216 & 8 & $.200^{*}$ \\
\hline & 5 & .220 & 8 & $.200^{*}$ \\
\hline
\end{tabular}


Berdasarkan hasil output uji kulit tubuh didapat nilai probalitas $(0,109$, Kolmogorov-Smirnov (SPSS 16) diatas, 0,200, 0,200, 0,200, 0,200>0,05). Artinya dapat dilihat tingkat signifikan atau distribusi kelima sampel adalah normal. probalitas kelima sampel dengan derają. Uji Homohenitas frekuensi 8 (8 x perlakuan) diatas 0,05 , $(0,125$, berdistribusi normal. Pada kehalusan kulit tubuh didapat nilai probalitas $(0,125,0,200,0,200,0,200$, $0,200>0,05)$, sedangkan pada kecerahan

Uji homogenitas dilakukan untuk mengetahui apakah keseluruhan sampel mempunyai kesamaan varians/homogen. Hasil output uji homogenitas dapat dilihat pada table berikut ini:

Tabel 6. Uji Homogenitas

\begin{tabular}{|c|c|c|c|c|}
\hline & $\begin{array}{l}\text { Levene } \\
\text { Statistic }\end{array}$ & df1 & df2 & Sig. \\
\hline Kehalusan & .522 & 4 & 35 & .720 \\
\hline Kecerahan & .360 & 4 & 35 & .836 \\
\hline
\end{tabular}

Data kelima varians dikatakan sama Penilaian pertama/kondisi awal (homogeny) jika probalitas $>0,05$ maka Ha (pretest) pada kelima sampel, indikator diterima. Hasil pada output uji levene test sebelum dilakukan perawatan lulur seruni di atas terlihat tingkat signifikansi atau nilai Mustika Ratu memiliki skor rata-rata 1,2 probalitas kehalusan dan kecerahan berada pada kehalusan dan kecerahan kulit tubuh diatas nilai $0,05(0,836$ dan $0,720>0,05)$, dengan kategori sedikit halus dan sedikit artinya kelima varians adalah sama. cerah.Hal ini dapat dilihat pada tabel

3. Deskripsi Hasil Penilaian Kulit Tubuh dibawah ini:

Sebelum Perawatan Lulur Pencerah

kulit dari kunyit 
Tabel 7. Skor Rata-rata Kehalusan dan Kecerahan Pretest/Sebelum Perlakuan Perawatan Kulit dengan Menggunakan Lulur Pencerah dari Kunyit

\begin{tabular}{|c|c|c|c|c|c|c|c|c|}
\hline \multirow[t]{2}{*}{ Indikator } & \multicolumn{5}{|c|}{ Sampel } & \multirow[t]{2}{*}{ Jumlah } & \multirow{2}{*}{$\begin{array}{c}\text { Rata- } \\
\text { rata }\end{array}$} & \multirow[t]{2}{*}{ Kategori } \\
\hline & 1 & 2 & 3 & 4 & 5 & & & \\
\hline Kehalusan & 1 & 1 & 1 & 1 & 2 & 6 & 1,2 & $\begin{array}{l}\text { Tidak } \\
\text { Halus }\end{array}$ \\
\hline Kecerahan & 1 & 2 & 1 & 1 & 1 & 6 & 1,2 & $\begin{array}{l}\text { Tidak } \\
\text { cerah }\end{array}$ \\
\hline
\end{tabular}

4. Deskripsi Hasil Penilaian Kulit Tubuh Setelah Dilakukan Perawatan Memanfaatkan Lulur Pencerah kulit dari kunyit (Postest).

Berdasarkan hasil penilaian yang diolah menggunakan uji one sample t test pada penelitian perawatan kulit tubuh memanfaatkan lulur seruni mustika tatu dengan frekuensi pemakaian 1 kali dalam 1 minggu, perubahan pencapaian pada setiap indikator telah terlihat pada perlakuan ke 3 berdasarkan perbandingan pada kondisi awal (pretest) dapat dilihat pada tabel rata-rata berikut ini:

Tabel 8. Skor Rata-rata Kehalusan dan Kecerahan postest/ setelah Perlakuan Perawatan Kulit dengan Menggunakan Lulur Pencerah dari Kunyit

\begin{tabular}{ccccccc}
\hline $\begin{array}{c}\text { Penialaian } \\
\text { ke }\end{array}$ & $\begin{array}{c}\text { Jumlah } \\
\text { skor }\end{array}$ & $\begin{array}{c}\text { Kehalusan } \\
\text { Rata- } \\
\text { rata }\end{array}$ & Kategori & $\begin{array}{c}\text { Jumlah } \\
\text { skor }\end{array}$ & $\begin{array}{c}\text { Kecerahan } \\
\text { Rata- } \\
\text { rata }\end{array}$ & Kategori \\
\hline $\mathbf{1}$ & 3 & 1,5 & $\begin{array}{c}\text { Sedikit } \\
\text { halus }\end{array}$ & 1 & 1,7 & $\begin{array}{c}\text { Sedikit } \\
\text { cerah }\end{array}$ \\
\hline $\mathbf{2}$ & 3,8 & 1,9 & $\begin{array}{c}\text { Sedikit } \\
\text { halus }\end{array}$ & 1,6 & 1,6 & $\begin{array}{c}\text { Sedikit } \\
\text { cerah }\end{array}$ \\
\hline $\mathbf{3}$ & 4 & 2 & $\begin{array}{c}\text { Sedikit } \\
\text { halus }\end{array}$ & 2,8 & 2,1 & $\begin{array}{c}\text { Sedikit } \\
\text { cerah }\end{array}$ \\
\hline $\mathbf{4}$ & 4,4 & 2,2 & $\begin{array}{c}\text { Sedikit } \\
\text { halus }\end{array}$ & 2,8 & 2,4 & $\begin{array}{c}\text { Sedikit } \\
\text { cerah }\end{array}$ \\
\hline $\mathbf{5}$ & 5 & 2,5 & $\begin{array}{c}\text { Sedikit } \\
\text { halus }\end{array}$ & 2,8 & 2,6 & Cerah \\
\hline $\mathbf{6}$ & 5,6 & 2,8 & Halus & 2,8 & 2,7 & Cerah \\
\hline $\mathbf{7}$ & 5,6 & 2,8 & Halus & 2,8 & 2,7 & Cerah \\
\hline $\mathbf{8}$ & 5,6 & 2,8 & Halus & 2,6 & 2,7 & Cerah \\
\hline
\end{tabular}


Untuk lebih jelasnya dapat diuraikan sebagai berikut:

\section{a. Kehalusan Kulit Tubuh}

Tingkat kehalusan kulit tubuh masing-masing sampel eksperimen penilaian ke-2 dan ke-3 dengan skor ratarata 1,5, 1,9 terkelompok dalam kategori sedikit halus. Kemudian pada penilaian ke4 dan ke-5 kondisi kulit berada pada skor rata-rata (2),(2,2) pada 14 kategori tetap yakni sedikit halus. Pada penilaian ke 6 hingga penilaian ke 8 terjadi peningkatan skor rata-rata yakni, $(2,5,2,8),(2,8)$ dan $(2,8)$ berada pada kategori halus.Berdasarkan data yang dihasilkan dapat dikatakan bahwa terdapat perubahan kehalusan kulit tubuh pada masing-masing sampel.

b. Kecerahan Kulit Tubuh
Tingkat kecerahan kulit tubuh masing-masing sampel eksperimen penilaian ke-2 dan ke-3 didapat skor ratarata 1,7 dan 1,6 dengan kategori sedikit cerah. Kemudian penilaian ke-4 dan ke 5, kondisi kulit berada pada kategori sedikit cerah dengan skor rata-rata 2,4 dan 2,6. Sedangkan pada penilaian ke 6 hingga penilaian ke-8kecerahan kulit mengalami peningkatan pada kategori cerah dengan skor ratarata, $(2,6),(2,7),(2,7)$, dan $(2,7)$.

Berdasarkan hasil data di atas dapat diartikan perawatan kulit tubuh dengan memanfaatkan lulur seruni Mustika Ratu dengan frekuensi 1 kali dalam 1 minggu memberikan perubahan yang nyata pada kehalusan dan kecerahan kulit tubuh. Kondisi perawatan kulit tubuh memanfaatkan lulur seruni dengan frekuensi 1 kali dalam 1 minggu dapat dilihat pada gambar histogram berikut ini:

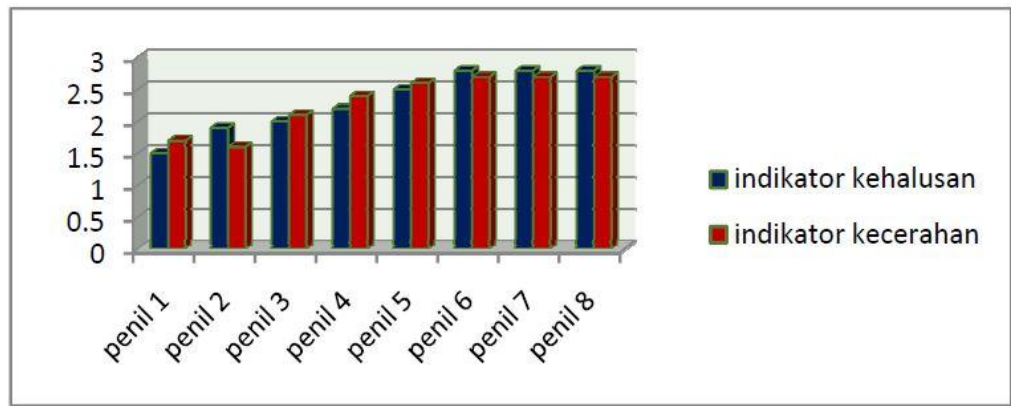


5. Hasil pengaruh pemanfaatan lulur perawatan kulit tubuh dengan pencerah kulit dari kunyit dengan memanfaatkan lulur pencerah kulit dari frekuensi 1 kali dalam 1 minggu kunyit pada setiap sampel dapat dilihat terhadap perawatan kulit tubuh pada tabel berikut ini :

Hasil dari penelitian yang dilakukan menunjukkan pengaruh yang signifikan dari

\begin{tabular}{|l|r|r|r|r|}
\hline & \multicolumn{1}{|c|}{$\mathrm{N}$} & \multicolumn{1}{c|}{ Mean } & \multicolumn{1}{c|}{$\begin{array}{c}\text { Std. } \\
\text { Deviation }\end{array}$} & \multicolumn{1}{c|}{$\begin{array}{c}\text { Std. Error } \\
\text { Mean }\end{array}$} \\
\hline Halus & 40 & 2.60 & .928 & .147 \\
Cerah & 40 & 2.38 & 1.005 & .159 \\
\hline
\end{tabular}

Tabel diatas merupakan output antara berada pada kategori halus. penilaian pada rata-rata dari hasil penelitian panelis indikator kecerahan kulit tubuh didapat menggunakan uji $\mathrm{t}$ (SPSS) terhadap skor rata-rata 2,38 (>2) dengan kategori seluruh sampel. pada indikator kehalusan sedikit cerah. kulit tubuh didapat skor rata-rata 2,06 (>2)

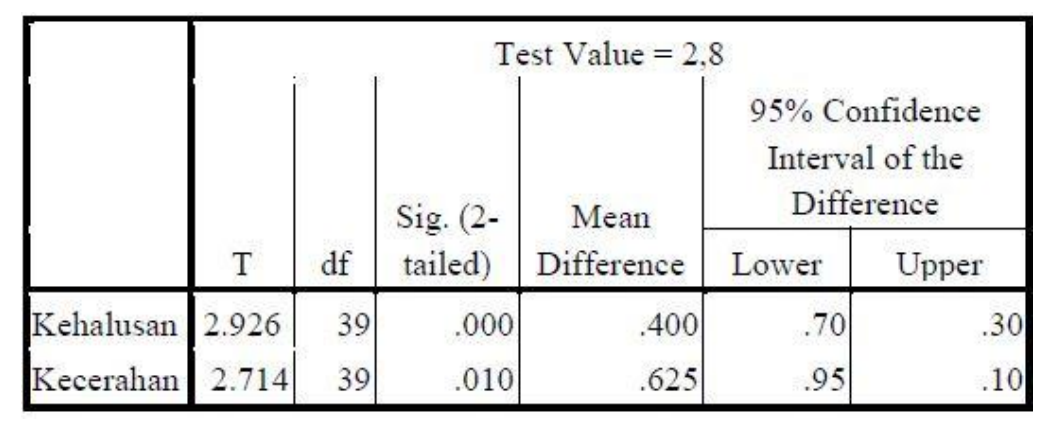

Berdasarkan hasil perhitungan $\mathrm{Uji} \mathrm{t}$ (One Sample $t$ Test) indikator dapat terlihat $\mathrm{t}$ (hitung) 3.591 kehalusan, $\mathrm{t}$ (hitung) 2.687 kecerahan > t (tabel) 2.022, yang berarti terdapat pengaruh yang signifikan terhadap masingmasing indikator dan terdapat tingkat keberhasilan perawatan kulit tubuh. Hasil penelitian di atas menunjukkan bahwa lulur pencerah kulit dari kunyit dapat menghaluskan dan mencerahkan kulit tubuh.

Pemakain lulur secara teratur maka selsel kulit mati yang menumpuk akibat kotoran yang dapat memicu timbulnya kusam pada kulit tubuh, akan terangkat dan menjadikan kulit bersih, halus, cerah serta mencegah keriput, 
memberikan nutrisi serta melembabkan kulit tubuh.

\section{KESIMPULAN}

Berdasarkan hasil analisis data yang diperoleh dari penelitian ini, dapat dirumuskan kesimpulan sebagai berikut: 1)

Pemanfaatan lulur seruni terhadap perawatan kulit tubuh dengan frekuensi pemakaian 1 (satu) kali dalam 1 minggu memperlihatkan pengaruh/perubahan pada kehalusan dan kecerahan kulit tubuh. Perubahan pada setiap indikator sudah terlihat pada perlakuan ke 3 namun untuk melihat perubahan yang lebih signifikan penulis melanjutkan penelitian hingga perlakuan ke-8), 2) Terdapat perbedaan pengaruh yang signifikan pemanfaatan lulur seruni terhadap perawatan kulit tubuh, dan setelah dianalisa dengan uji t/one sample $t$ test. Berdasarkan analisis tersebut tingkat pengaruh yang paling baik adalah pengaruh pada indikator kehalusan.

\section{DAFTAR PUSTAKA}

Anonim, 2006. Indeks Tumbuh- Tumbuhan Obat Indonesia, Edisi Ke- 2, PT. Eisai Indonesia, hlm.271

Desyntia, D. 2012. Sehat Dengan Secangkir

Kopi. Surabaya: Stomata
Fauzi, Aceng Ridwan dan Nurmalina, Rina. 2012. Merawat Kulitdan Wajah. Jakarta: PT. Elex Media Komputindo. Heriana, Arief. 2013. 262 TumbuhanObat Dan Khasiatnya.PenebarSwadaya: Jakarta.

Tranggono, Retno Iswari dan Latifah, F. 2007. Buku Pegangan Ilmu Pengetahuan Kosmetik. Gramedia Pustaka Utama, Jakarta.

Gozali, D., Abdassah, M., dan Lathiefah, S., 2009, Formulasi Krim Pelembab Wajah yang Mengandung Tabir Surya Nano Partikel Zink Oksida Salut Silikon, Jurnal Farmaka. 